UDC 338.242

JEL Classification: F23, M14

http://doi.org/10.21272/mmi.2019.2-19

Richard Szanto,

Ph.D., Associate professor, Corvinus University of Budapest, Hungary

\title{
CSR DILEMMAS AT MULTINATIONAL COMPANIES: GLOBAL PRESSURES VS. LOCAL EXPECTATIONS IN THE LIGHTS OF THE HUNGARIAN EVIDENCE
}

\begin{abstract}
Several studies have confirmed that the implementation of corporate social responsibility (CSR) initiatives and activities of multinational companies (MNCs) differed across locations. Subsidiaries of MNCs must both respond to internal pressures coming from global headquarters and expectations of local stakeholders. The major research questions of the study are the following: What are the major drivers of their CSR activities and how do they balance between the global pressure of MNC headquarters and the expectations of the local stakeholders? What coping mechanisms do they implement in order to tackle the CSR challenges? As a result of conducting 10 semi-structured research interviews at Hungarian subsidiaries, 3 key CSR challenges, and 7 coping mechanisms were identified. The 3 major challenges include the lack of financial and human resources dedicated to CSR activities, the lack of legal or cultural support of the headquarters' initiatives in the host country, and the difficulty to form an effective CSR strategy to respond to the various needs of local stakeholders. The subsidiaries use different coping mechanisms to tackle the challenges. They usually pursue continuous bargaining with MNC HQs in order to have sufficient financial resources for local CSR actions and to get freedom for creating their own CSR approaches reacting to genuine local needs. If they are not able to accumulate plentiful resources, they may implement a low key or minimalistic CSR strategy that usually means solely philanthropy or charity. When host country social values do not meet global MNC norms, subsidiaries often choose to turn inward, i.e. promoting global values only inside the company in daily operations, and not propagating these values to the wider public. Nevertheless, the most prevalent strategy may be more careful balancing between global MNC norms and local values. Subsidiaries use various mechanisms to detect the needs of their key stakeholders and to create those actions that can be the most vital elements of their local CSR strategies. They often co-operate with NGOs and/or the local government to reach their CSR objectives. Numerous subsidiaries do business integrated CSR to serve local stakeholders' needs in the most effective way. Finally, most subsidiaries are constantly scanning MNC units in the region to find out how they confront their local CSR challenges. This mechanism seems to work well due to similarities among host country cultures in the CEE region.
\end{abstract}

Keywords: coping mechanisms, corporate social responsibility, local vs. global CSR, multinational companies, subsidiaries.

Introduction. Academic interest in the international dimension of Corporate Social Responsibility (CSR) has been constantly growing in the last three decades (Pisani et al, 2017), but the CSR practices of multinational companies (MNCs) in particular, have not been discussed so intensively. As Byung Park and Pervez Ghauri put it: «Although CSR issues are thoroughly dealt within some academic areas, such as Strategic Management and Marketing, their implications for MNE [Multinational Enterprise] subsidiaries associated with CSR have been largely overlooked in International Business research» (Park \& Ghauri, 2015: 202). This viewpoint is echoed by Hah and Freeman (2014) who suggest that the literature in this field is still in its infancy despite the significant scholarly interest toward the intersection of MNC and CSR researches. This tendency may be explained with the widely shared assumption that in the very special context of MCSs, CSR is even more difficult to define (Rodriguez et al, 2006). Although emerging economies face various economic and social challenges that are less known, or even unknown to developed countries, such as transition problems in Central and Eastern Europe (Sroka \& Szanto, 2018), extreme growth dilemmas in China, or high inequality in India or Brazil (Cruz \& Boehe, 2010), international CSR literature rarely deal explicitly with these regions or countries. As Pisani and his co-authors claim: «For instance, looking at the various regions covered, there is a dearth of CSR

Cite as: Szanto, R. (2019). CSR Dilemmas at Multinational Companies: Global Pressures vs. Local Expectations in the Lights of the Hungarian Evidence. Marketing and Management of Innovations, 2, 217-227. http://doi.org/10.21272/mmi.2019.2-19 
R. Szanto. CSR Dilemmas at Multinational Companies: Global Pressures vs. Local Expectations in the Lights of the Hungarian Evidence

research focused on Central and Eastern Europe (CEE) and Africa in the management literature» (Pisani et al, 2017: 597). This paper tends to fill this gap by investigating CSR challenges and practices of Hungarian subsidiaries of MNCs. The major research questions of the study are the following: What are the major drivers of their CSR activities and how do they balance between the global pressure of MNC headquarters and the expectations of the local stakeholders? What coping mechanisms do they implement in order to tackle the CSR challenges? Although some CEE countries such as Hungary, are in the borderline between developed and emerging economies in terms of GDP per capita, this study can contribute to the academic literature in several ways. To the author's best knowledge, no research has been carried out in the past that investigated CSR challenges and the coping mechanisms of subsidiaries in CEE context. Another contribution advances a better understanding of what factors shape the CSR strategies and practices of subsidiaries. In order to identify these factors, this paper takes the perspective of the subsidiaries, therefore it explores only the perception of the local managers. In the next chapter, a literature review will be made, then the qualitative methodology applied will be introduced. Then 3 key CSR challenges of the Hungarian subsidiaries will be introduced, and 7 coping mechanisms that companies use as reactions to these challenges. Finally, the conclusion and some possible future research directions will be presented at the end.

Literature Review. The concept of CSR has been commonly discussed and often contested in the literature, there has been a jungle of definitions in this field (Crane et al, 2013; Kolk, 2016; ChwisteckaDudek, 2016). In this paper, we are going to use the widely accepted definition of Matten and Moon, who claims that «the core of CSR is the idea that it reflects the social imperatives and the social consequences of business success» (Matten \& Moon, 2008). After reviewing the academic literature on the intersection of CSR and international business it is noticeable that neo-institutional theory might have developed the most pertinent concepts that are used as frameworks in these studies, namely isomorphism and legitimacy (Beddewela \& Fairbass, 2016). According to institutional theory (Meyer \& Rowan, 1977; DiMaggio \& Powell, 1983) organizations adopt policies and practices to look to be in alignment with the institutions that can be understood as «rules of the game» in a given country (Rathert, 2016). The most theoretical framework of this field considers CSR as an important legitimization tool that was reaffirmed by many empirical studies (Hah and Freeman, 2014; Miska et al, 2016; Park et al, 2014). Most studies confirm that subsidiaries of MNCs at different locations usually engage in CSR activities in various ways. Both the intensity and the orientation of CSR actions can differ across geographical locations, as Rodriguez et al. (2006: 737) put it: «...business norms and standards, regulatory frameworks and political systems, corruption, and stakeholder demand for CSR can vary substantially across nations, regions, and lines of business». Some research shows a clear divergence of CSR practices around the world. CSR practices in the developing world are often characterized as narrow, focusing more on philanthropy, while western world type CSR is more diverse (Jamali \& Neville, 2011). Concerning MNCs, the most evident differences can be traced between the approaches of global headquarters and the ones of distant locations (Campbell et al, 2016). A great body of academic literature applies the integration-responsiveness framework by Bartlett and Ghoshal (1989), interpreting the global-local CSR challenge as part of a more general dilemma of multinational companies (Miska et al, 2016). What strategic principle should receive more emphasis in the host countries: global integration or local responsiveness? Beyond these two, however, MNCs must also create platforms for global learning, in order to diffuse knowledge from individual subsidiaries to the rest of the MNC network, and vice versa (Cruz \& Boehe, 2010). Logsdon and Wood (2002) recommend a 3-step hybrid strategy for multinationals to operationalize CSR or business citizenship: first, they should adopt a global credo, the (hyper)norms that govern operations across the globe. Second, this credo is applied in the host countries, reflecting on local norms without violating the global principles. At step 3, the MNC conducts experiments that fit the host country's norms and also support global principles. These findings indicate 
R. Szanto. CSR Dilemmas at Multinational Companies: Global Pressures vs. Local Expectations in the Lights of the Hungarian Evidence

that MNCs must differentiate between «local» and «global» CSR when they implement their CSR strategy. As Husted and Allen state: «Thus, «local» CSR deals with the firm's obligations based on the standards of the local community, whereas «global» CSR deals with the firm's obligations based on those "standards to which all societies can be held» (Husted \& Allen (2006: 840). UN Sustainable Development Goals (SDGs) are good examples of elements of global CSR. CSR communication of many MNCs revolve around UN SDGs, they often use it as an integrative framework for their CSR principles and actions (Szanto, 2018). Nonetheless, one may acknowledge that global CSR values often originate from the country where the MNC headquarters are located (in most cases from WesternEurope or the US), or more directly from the owners (in case of family ownership for example). Some studies demonstrate that «local» and «global» CSR strategies can co-exist, but it varies a lot which one receives greater attention. In their seminal paper Husted \& Allen (2006), using Bartlett and Ghoshal typology, suggest that multi-domestic and transnational MNCs in developing economies place greater emphasis on country-specific CSR than global ones. It means MNCs' CSR practices are consistent with organization strategy. Jamali (2010) had similar results in the Lebanese context: although MNC headquarters diffuse their CSR strategies to the subsidiaries, these strategies are often diluted at the local level because of the market characteristics and the expectations of the stakeholders in the host country. Different cultural contexts were investigated in several developing and emerging economies, for example in Sri Lanka (Beddewela \& Fairbrass, 2016), in Lebanon (Jamali, 2010), in China (Yin \& Jamali, 2016), in South Korea (Park et al, 2014), or in Brazil (Cruz \& Boehe, 2010). Surroca et al. (2013) investigate the transfer of corporate social irresponsibilities from parent to subsidiaries, especially when at headquarters $(\mathrm{HQ})$ level stakeholder pressure increases. Therefore, subsidiaries of MNCs may want to gain legitimacy in host countries by implementing CSR practices. Contrary to this Tan \& Wang (2011) claim that MNCs often take advantage of the weak institutions in host countries instead of applying the same standards that are introduced in home countries. Nevertheless, CSR practices can even produce a negative perception of local stakeholders if they do not believe in the positive motives that drive their actions (Crilly et al, 2016).

Methodology and research methods. In order to explore the major internal and external forces shaping the CSR practices of Hungarian subsidiaries of MNCs, a qualitative research methodology was carried out. Although the application of qualitative research methodologies is less frequent in international CSR literature, there are several exceptions. Mohan (2006) for example applies the embedded multiple case study design by investigating only two UK based MNCs in her study, while Miska and his co-authors (2016) use content analysis methodology on a pool of CSR-related documents of Chinese MNCs. Jamali (2010) conducted in-depth research interviews with representatives of 10 Lebanese subsidiaries of MNCs, while Yin and Jamali (2011) used the same methodology inspecting the CSR practices of 11 Chinese companies. In this study, a similar research design was carried out. 10 semi-structured research interviews were conducted with representatives of Hungarian subsidiaries (for the full list, see Table 1).

Table 1. Main characteristics of the research interviews

\begin{tabular}{|c|c|c|c|}
\hline Code & HQ & Industry & Position of the interviewee \\
\hline $\mathbf{1}$ & $\mathbf{2}$ & $\mathbf{3}$ & $\mathbf{4}$ \\
\hline MNC1 & Europe & Food \& beverages & $\begin{array}{c}\text { Human Resources and Corporate } \\
\text { Affairs Director }\end{array}$ \\
\hline MNC2 & Americas & Food \& beverages & External communications lead \\
\hline MNC3 & Americas & Telecommunications & Head of Corporate Communications \\
\hline MNC4 & Europe & $\begin{array}{c}\text { Fast moving consumer } \\
\text { goods }\end{array}$ & Communications manager \\
\hline
\end{tabular}


R. Szanto. CSR Dilemmas at Multinational Companies: Global Pressures vs. Local Expectations in the Lights of the Hungarian Evidence

\begin{tabular}{|c|c|c|c|}
\multicolumn{2}{c|}{ Continue Table 1. } \\
\hline $\mathbf{1}$ & $\mathbf{2}$ & $\mathbf{3}$ & $\mathbf{4}$ \\
\hline MNC5 & Europe & Telecommunications & CR Communications expert \\
\hline MNC6 & Europe & Wholesale \& retail & Head of communications \\
\hline MNC7 & Asia-Pacific & $\begin{array}{c}\text { Electronics, machinery, \& } \\
\text { tools }\end{array}$ & PR specialist \\
\hline MNC8 & Asia-Pacific & Food \& beverages & Head of Corporate Affairs \\
\hline MNC9 & Europe & Wholesale \& retail & $\begin{array}{c}\text { Head of Communications and } \\
\text { Campaigns }\end{array}$ \\
\hline MNC10 & Europe & Energy & Member of the board of directors \\
\hline
\end{tabular}

Sources: compiled by the author.

During the process, 25 MNCs were targeted, but only 10 companies (40\% response rate) accepted the invitation for participating in a research interview. One subsidiary refused to take part in this research due to the lack of time, 3 others postponed the interview for similar reasons, hence they were not included in this sample. One subsidiary rejected the request, because of their global policy on information disclosure, while other 2 companies claimed that they had too few CSR activities, therefore they did not want to take part in this research. The rest (8 companies) did not answer our request at all due to any reasons. Before conducting the research interviews all publicly available relevant (i.e. CSR related) documents (reports, online content, etc.) were collected and scrutinized in order to support preparation for the interviews.

The headquarters of the MNCs are located in different continents, 6 companies are from Europe, 2 from the Americas, and another 2 from the Asia-Pacific region. European multinationals are a bit overrepresented in the sample, so does the food and beverages industry. Although diversity was an important objective, some specific industries are not represented at all such transportation \& logistics, construction, and metal processing. The 10 Hungarian subsidiaries in the sample employ 44,302 people together and had 2,610.77 billion HUF (8.16 billion EUR) revenues in 2017. For the interviews, a semistructured questionnaire was developed. The interviews usually took place at the premises of the companies, in one case at the university where the author is employed. The longest interview took almost 1.5 hours, while the shortest 36 minutes. The average length of the interviews was 53.4 minutes. The person answering the questions usually was responsible for corporate communications, but in some cases, he or she was from a different level of the hierarchy (see Table 1 for details). The research interviews were conducted in April and May 2019. All research interviews were fully recorded, then transcribed. During analysis, the author was seeking for recurring patterns and themes in the texts across the interviews (Miles \& Huberman, 1994). This pattern coding was also applied by Yin and Jamali (2016) in a similar fashion when they analyzed several semi-structured interviews, they conducted at Chinese subsidiaries of MNCs. When pattern codes were created, some common themes and topics were sought across the interviews. These common themes were grouped into larger categories; they will be presented in the next chapter as challenges or coping mechanisms of the subsidiaries.

Results. In this chapter, the main CSR challenges of the Hungarian subsidiaries and their coping mechanisms will be discussed (see Figure 1). Though the following items were frequently mentioned by the representatives of the subsidiaries, one may not forget that generalization in case of qualitative research can be done with great reservations. It is also evident that subsidiaries operate in a fairly dynamic environment (one of the subsidiaries in the sample, for example, has been just recently acquired, while another one was just waiting for the approval of an acquisition). Understaffing and/or under-financing. Although most interviewees underlined their independence from the MNC headquarters concerning their CSR approach, they also admitted, though, to various extent, that central financial 
R. Szanto. CSR Dilemmas at Multinational Companies: Global Pressures vs. Local Expectations in the Lights of the Hungarian Evidence

control might make a significant burden on host country CSR programs. Therefore, subsidiary managers may have to cut or reduce the volume of host country-specific programs responding to local stakeholder demands due to cost control of the $\mathrm{HQ}$. These findings resonate with the similar tensions described by Cruz and Boehe (2010). Some CSR related proposals might be rejected because of financial reasons. This kind of control can be characterized as a semi-control mechanism, that is fairly loose regarding some CSR programs implemented by the subsidiary in the host country, but rather strict regarding financial budgets. Local culture and legal framework vs. global initiatives. It is apparent from the interviews that there are often tensions between the (western) values and principles that are represented by the MNCs and the ones embraced by the culture of the host country. An emblematic example of this phenomenon how MNCs deal with values like diversity, inclusiveness, or equality. Most MNCs in the sample address in their communications the importance of the inclusion and acceptance of minorities of any kind, the equality between sexes, etc. However, the more conservative and masculine Hungarian (and in a broader context Central and Eastern European) culture does not necessarily embrace these values with the same intensity.

Host country legal regulations in some cases may ease, in some cases may harden the engagement of $\mathrm{HQ}$ CSR principles. When an $\mathrm{HQ}$ CSR principle is in alignment with local legal regulations, subsidiaries may easily internalize it. When for example a multinational manufacturer of alcoholic beverages introduced «when drive, do not drink» slogan, it was easily adopted in Hungary where there is zero tolerance with drunk driving. However, other subsidiaries where moderate alcohol consumption is allowed while driving (like in the U.S.) refused to endorse the global direction. Identification of local CSR issues. It is evident that subsidiaries in many cases have great difficulties to identify those topical areas or issues they could form their CSR activities around. They usually look for topics/issues that somehow can be connected to the brands (to the products or services), are in alignment with global policies, are relevant to the host country, are affordable to the subsidiary, and can be communicated to the wider public. Beyond these requirements scaling is typically a critical factor, subsidiaries seek for CSR actions that may generate a significant impact in the society. In order to tackle the key CSR challenges that were presented in the previous chapter, subsidiaries developed various coping mechanisms. Of course, due to the qualitative research methodology, generalization is not possible here either, and one should note that different subsidiaries engage in these coping mechanisms to various extent. These mechanisms do not exclude each other; hence subsidiaries may use them in a parallel fashion. Some coping mechanisms can be used in case of multiple challenges as Figure 1 presents. Focusing on internal CSR activities («Turning inward»), for example, can be a strategic response to the lack of financial or human resource, but also to the mismatch between global MNC norms and host country cultural values. In Table 2 some quotes are presented from the interviews to illustrate these mechanisms.

Continuous bargaining with MNC headquarters. It seems apparent from the interviews that corporate headquarters usually put a strong emphasis on various forms of corporate social responsibility, but they are also aware of the local context in the host countries. Nevertheless, the latter does not mean that HQs do not put pressure on their subsidiaries to carry out global CSR programs. Host country subsidiaries often have to convince $\mathrm{HQs}$ that certain CSR actions would not work in the host country, or even would generate hostility from local stakeholders. The subsidiaries of the sample seemed to be very successful in these bargaining processes, and they often achieved significant level of freedom in their CSR approach. Host country initiatives in most cases received a green flag from HQs, but when it required too large investments, they might have stopped the program. Yet, environmental principles and goals are rarely negotiable, subsidiaries usually must comply with $H Q$ expectations. Using the terminology of Husted and Allen (2006), concerning green and environmental issues «global» CSR receives more attention, and subsidiaries have no freedom for doing «local» CSR. Low key / minimalistic CSR. 
R. Szanto. CSR Dilemmas at Multinational Companies: Global Pressures vs. Local Expectations in the Lights of the Hungarian Evidence

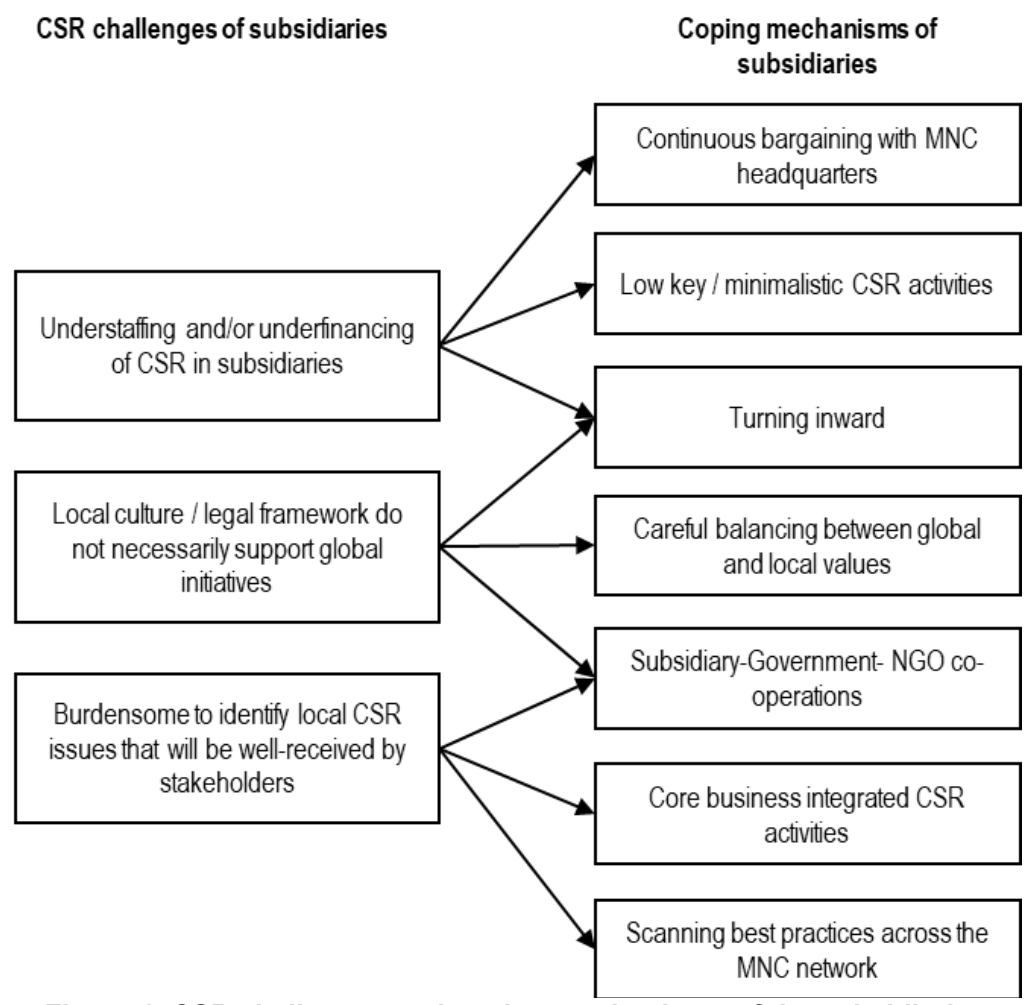

Figure 1. CSR challenges and coping mechanisms of the subsidiaries

Sources: compiled by the author.

Table 2. Quotes on local coping mechanisms

\begin{tabular}{|c|c|}
\hline $\begin{array}{c}\text { Coping local } \\
\text { mechanisms }\end{array}$ & Illustrative quotes \\
\hline $\mathbf{1}$ & \multicolumn{1}{c|}{ 2 } \\
\hline $\begin{array}{c}\text { Continuous bargaining } \\
\text { with MNC headquarters }\end{array}$ & $\begin{array}{c}\text { "l was working at other multinationals as well, I am not saying company } \\
\text { names now, but they often put subsidiaries into strong hierarchies. At our } \\
\text { company, subsidiary and parent company work together in interesting and } \\
\text { continuous cooperation» (MNC3) } \\
\text { "There are some disentangled subsidiaries, who can implement their own } \\
\text { actions. But it is true at the group level that the subsidiaries are free to do } \\
\text { their initiatives adjusted to the local context, of course, until they comply } \\
\text { with the global sustainability principles» (MNC5) }\end{array}$ \\
\hline Low key / minimalistic \\
CSR activities & $\begin{array}{c}\text { «lf I consider Hungary, to be honest, we do not have CSR dedicated } \\
\text { budget, therefore all of our actions are very ad-hoc, and it depends on } \\
\text { which division has enough surplus in its marketing budget that we can } \\
\text { spend on the donation that we know is needed since we were asked to } \\
\text { donate. We always try to donate in a way that we give our products and } \\
\text { not just money» (MNC7) }\end{array}$ \\
\hline
\end{tabular}


R. Szanto. CSR Dilemmas at Multinational Companies: Global Pressures vs. Local Expectations in the Lights of the Hungarian Evidence

\begin{tabular}{|c|c|}
\hline 1 & 2 \\
\hline $\begin{array}{l}\text { Careful balancing } \\
\text { between global and } \\
\text { local values }\end{array}$ & $\begin{array}{l}\text { «lt was a very strong commitment, and it was very successful in Mexico. } \\
\text { But we were discussing if this campaign was working in Hungary, and we } \\
\text { concluded that it would not. (...) There are different social challenges, } \\
\text { different attitudes, and it is totally normal. And I think, it is very good that } \\
\text { we have the freedom to decide about it locally» (MNC1) } \\
\text { «We have a campaign where certain parts (but not the whole) were taken } \\
\text { out from the Hungarian adaptation because we felt that a transgender } \\
\text { woman would not be received very well in the Hungarian market by local } \\
\text { consumers. Other parts [of the campaign] remained, but we had an } \\
\text { impression that this topic had been a little bit risky here. The campaign, } \\
\text { therefore, was adopted in a simplified version» (MNC4) }\end{array}$ \\
\hline Turning inward & $\begin{array}{l}\text { «We also have [diversity programs], but we keep them inside the } \\
\text { company. (...) There are some [principles] we handle with care. We know } \\
\text { that they are important for the mother company, and we convey the } \\
\text { message inside, because we expect our employees to embrace these } \\
\text { values, but we would not do it necessarily outside» (MNC5) } \\
\text { «This [initiative] was created around the topic of plastic that is a hot issue } \\
\text { nowadays. I would like to underline the initiative that we launched here in } \\
\text { Hungary. Moreover, a small self-organizing community among our } \\
\text { employees started it. They wanted to implement such programs that } \\
\text { contributed to the plastic waste reduction at the local level a little bit } \\
\text { beyond the global principles of the company» (MNC4). }\end{array}$ \\
\hline $\begin{array}{l}\text { Subsidiary- } \\
\text { Government- NGO co- } \\
\text { operation }\end{array}$ & $\begin{array}{c}\text { «l think, we can respond to social problems well if all three parties are } \\
\text { present - i.e. the Hungarian state, an NGO, and a for-profit organization. I } \\
\text { think it works well this way» (MNC2) }\end{array}$ \\
\hline $\begin{array}{l}\text { Core business } \\
\text { integrated CSR } \\
\text { activities }\end{array}$ & $\begin{array}{l}\text { «For us, as a service provider, it is important that more and more people } \\
\text { should use the digital solutions we offer. (...) In the case of local CSR, we } \\
\text { always connect [the activity] to the brand and to the profile of the } \\
\text { company. Our competitors think in the same way regarding their digital } \\
\text { competence and development programs - actions on cybersecurity, } \\
\text { digital school, etc. are everywhere [in the industry]» (MNC5) }\end{array}$ \\
\hline $\begin{array}{l}\text { Scanning best } \\
\text { practices across the } \\
\text { MNC network }\end{array}$ & $\begin{array}{l}\text { "The HQ has a communication department, where there is knowledge } \\
\text { sharing. We have an internal system through we can share these } \\
\text { solutions if they are not publicly available. If they are, and it can be shared } \\
\text { with everyone, then it is uploaded to our international webpage, and } \\
\text { anyone can learn about it. This system has a goal that in all } 48 \text { countries } \\
\text { under the corporate umbrella everybody should be informed about what } \\
\text { happens in other countries. It applies to anything else, not just to CSR» } \\
\text { (MNC6) }\end{array}$ \\
\hline
\end{tabular}

Sources: compiled by the author.

Although it is not a widespread strategic response, some subsidiaries turn to this mechanism if they have an impression that they cannot afford large scale CSR programs. In these cases, subsidiaries usually limit their CSR activities to donations and charity that are frequently not even connected to the profile, or to MNC brands. 
R. Szanto. CSR Dilemmas at Multinational Companies: Global Pressures vs. Local Expectations in the Lights of the Hungarian Evidence

Findings of other studies (Pataki et al, 2015; Szanto, 2018) suggest that MNCs that are engaged mostly in B2B transactions and are not in direct relationship with end users (for example automotive suppliers) also implement fairly narrow CSR actions mostly focusing on the local communities where they hold larger production facilities.

Subsidiaries often realize that either they do not have the resources to execute rich CSR programs or the society in the host country would not receive well some initiatives that were formed at the group level. Consequently, they may choose the «turning inward» strategy. It means that they promote CSR activities mostly inside the company, besides they put a strong emphasis on group level goals at internal operation. However, they do not necessarily make such actions outside the company to promote these MNC norms at the societal level. For example, a «turning inward» coping strategy is when the subsidiary enforces diversity and equality principles inside the boundaries of the company, but do not communicate about these values vehemently outside the company. "Turning inward» can be also beneficial if the subsidiary does not have the financial or other resources since they do not have to implement often costly nationwide campaigns. Careful balancing between global and local values. As it was mentioned earlier, in case of a mismatch between host country cultural values and global MNC norms, host country subsidiaries normally do not even try to implement campaigns aiming at propagating these norms, or if they do so, they often fail. The most interviewees were convinced, however, that MNCs (and their subsidiaries) ought to raise awareness and sensitize the host country society even if it may generate some contradictions. Therefore, a limited number of CSR activities are implemented to raise awareness of certain social issues, but in a very careful, balanced way. For example, LGBTQ rights are probably not discussed due to the hostility that has been seen recently in Hungary, but less sensitive issues such as women rights or other minority rights may be embraced by certain CSR campaigns in a reserved way. In other cases, global campaigns were adapted in a simplified version, or some risky or sensitive topics were taken out. This coping mechanism is in alignment with the normative model of Logsdon and Wood (2002) who suggest that global initiatives and host country norms should be reconciled.

Although explicitly it was never asked, the role and support of the local government often appeared as a topic during the interviews. Some interviewees talking about their favourite host country CSR activities underlined the importance of the support of the government. This may suggest that the Hungarian government is a stakeholder with key importance for the local subsidiaries even regarding their CSR activities. This tendency is not surprising when one takes into consideration the rise of the socalled political corporate social responsibility - i.e. CSR actions that have intended or unintended political impact (Frynas \& Stephens, 2015). Countless CSR activities are implemented by the MNC subsidiaries in collaboration with non-governmental organizations (NGOs). Although there are some few exceptions, large CSR programs, initiatives typically have an NGO pillar. These NGOs often provide channels to the final beneficiaries of the CSR programs, consequently, the subsidiary heavily relies on the infrastructure of the NGO, but the NGO also enjoys the benefits of the financial (or in-kind) support of the MNC. One of the major challenges is to identify those NGOs who are capable to co-operate with the MNC. In some cases, it is the $\mathrm{HQ}$ that decide which NGO the subsidiary should work with, but it is more typical that the local MNC unit has the freedom to select which organizations they want to collaborate with. These types of collaborations have received growing attention in the CSR literature, where researchers identified several forms of partnerships such as corporate foundations, joint ventures, etc. Although these co-operations may exploit synergies, there is a potential risk, especially in developing and emerging economies, that companies simply outsource - at least partly - their CSR programs to the third party (Jamali \& Kechichian, 2008). In some special cases, the subsidiary, the local government and an NGO can work on the CSR initiative together. The representatives of the subsidiaries considered these collaborations as the highest level of social partnerships that one can reach in a CSR activity. Working with an NGO and the local government at the same time may generate an additional level of 
R. Szanto. CSR Dilemmas at Multinational Companies: Global Pressures vs. Local Expectations in the Lights of the Hungarian Evidence

legitimacy to the MNC, but the subsidiary can also learn from these co-operations about the needs of local stakeholders. The study of Park et al. (2014) also shed light on the importance of these two secondary stakeholders (local government and NGOs) in an emerging market context.

More and more subsidiaries have been seeking ways to integrate their CSR practice into their dayto-day business operations. Hence, CSR is not a separate island inside the business entity or just another form of corporate communication, but an integral part of the business model that is carried out in the host country (Wisniewski, 2015). This is also called an embedded CSR approach when there is a clear integration of CSR into the company core business (Aguinis \& Glavas, 2013). This way subsidiaries of MNCs can identify their mechanisms through which CSR influences stakeholders, not only the benefits that CSR brings to the organization and the stakeholders.

Lastly, most subsidiaries are constantly scanning CSR actions carried out by other MNC units in the network. In other words, subsidiaries watch each other and attempt to adopt initiatives from other countries if they believe they would work in their own local context. In the academic literature studies usually, focus on the knowledge transfer from MNC HQ to the subsidiaries, and often disregard the global learning opportunities across the subsidiaries (Cruz \& Boehe, 2010). In the one hand, due to the cultural and institutional similarities among countries in the same region, learning can be very effective and efficient. On the other hand, even in the same region, there might be some differences that ought to make subsidiaries cautious to take CSR actions in an identical way without adjustments.

Conclusions. More than a decade ago, Rodriguez and his co-authors (2006) contemplated that the literature on MNCs and CSR had been in an embryonic phase. Even though there are still some blind spots 15 years later, we know much more about the CSR practices of the MNC sector and their motives behind. There have been delivered numerous studies that were discussing the CSR strategies of multinationals differentiating between «global» and «local» CSR. This paper contributes to the academic literature by investigating the Hungarian context and exploring the major CSR challenges of the subsidiaries and their coping mechanisms. As a result of conducting 10 semi-structured research interviews at Hungarian subsidiaries, 3 key CSR challenges, and 7 coping mechanisms were identified. The 3 major challenges include the lack of financial and human resources dedicated to CSR activities, the lack of legal or cultural support of the headquarters' initiatives in the host country, and the difficulty to form an effective CSR strategy to respond to the various needs of local stakeholders. The subsidiaries use different coping mechanisms to tackle the challenges. They usually pursue continuous bargaining with MNC HQs in order to have sufficient financial resources for local CSR actions and to get freedom for creating their own CSR approaches reacting to genuine local needs. If they are not able to accumulate plentiful resources, they may implement a low key or minimalistic CSR strategy that usually means solely philanthropy or charity. This coping mechanism, yet, was not widespread in the sample. When host country social values do not meet global MNC norms, subsidiaries often choose to turn inward, i.e. promoting global values only inside the company in daily operations, and not propagating these values to the wider public. Nevertheless, the most prevalent strategy may be more careful balancing between global MNC norms and local values. Subsidiaries use various mechanisms to detect the needs of their key stakeholders and to create those actions that can be the most vital elements of their local CSR strategies. They often co-operate with NGOs and/or the local government to reach their CSR objectives. Numerous subsidiaries do business integrated CSR to serve local stakeholders' needs in the most effective way. Finally, most subsidiaries are constantly scanning MNC units in the region to find out how they confront their local CSR challenges. This mechanism seems to work well due to similarities among host country cultures in the CEE region. One may not forget that this study was carried out on a relatively small and not representative sample. Some industries were not even represented; therefore, some key CSR challenges might have not been recognized. This paper examined the CSR challenges and coping mechanisms of MNCs only from the subsidiaries' 
R. Szanto. CSR Dilemmas at Multinational Companies: Global Pressures vs. Local Expectations in the Lights of the Hungarian Evidence

perspectives. Future studies can investigate global/local CSR dichotomy from HQ viewpoint as well and can compare CSR actions and principles at the global, regional and local level. Studies dealing with MNCs and CSR almost totally neglect regional perspective, albeit the findings of this research demonstrate that various CSR actions and initiatives of the same MNCs are very similar even in larger regions. In order to explore these tendencies, CSR practices of different subsidiaries of the same MNC should be scrutinized in various sectors. As a result, one may be able to demonstrate similarities and differences across host countries in the same region.

\section{References}

Aguinis, H., Glavas, A. (2013). Embedded versus peripheral corporate social responsibility: psychological foundations'. Industrial and Organizational Psychology: Perspectives on Science and Practice, 6(4), 314-332.

Bartlett, C.A., Ghoshal, S. (1989). Managing across borders: The transnational solution. Boston, MA: Harvard Business School Press.

Beddewela, E., Fairbrass, J. (2016). Seeking Legitimacy Through CSR: Institutional Pressures and Corporate Responses of Multinationals in Sri Lanka, Journal of Business Ethics, 136, 503-522.

Campbell, J.T., Eden, L., \& Miller, S.R. (2012). Multinationals and corporate social responsibility in host countries: Does distance matter?, Journal of International Business Studies, 43(1): 84-106.

Crane, A., Matten, D., and Spence, L.J., (2013). Corporate Social Responsibility in a Global Context, In. Crane, A., Matten, D., and Spence, L.J., Corporate Social Responsibility: Readings and Cases in a Global Context, 2/e. (pp. 3-26), Abingdon: Routledge.

Crilly, D., Ni, N., Jiang, Y. (2016). Do-no-harm versus do-good social responsibility: Attributional thinking and the liability of foreignness, Strategic Management Journal, 37(7), 1316-1329.

Cruz, L.B., Boehe, D.M. (2010). How do leading retail MNCs leverage CSR globally? Insights from Brazil. Journal of Business Ethics, 91(2), 243-263.

Chwistecka-Dudek, H. (2016). Corporate Social Responsibility: supporters vs. opponents of the concept, Forum Scientiae Oeconomia, 4(4), 171-179.

DiMaggio, P.J., Powell, W.W. (1983). The Iron Cage Revisited: Institutional Isomorphism and Collective Rationality in Organizational Fields, American Sociological Review, 48(2), 147-160.

Frynas, J.G., Stephens, S. (2015). Political Corporate Social Responsibility: Reviewing Theories and Setting New Agendas, International Journal of Management Reviews, 17(4), 483-509.

Hah, K., Freeman, S. (2014). Multinational Enterprise Subsidiaries and their CSR: A Conceptual Framework of the Management of CSR in Smaller Emerging Economies, Journal of Business Ethics, 122: 125-136.

Husted, B., Allen, D. (2006). Corporate social responsibility in the multinational enterprise: strategic and institutional approaches, Journal of International Business Studies, 37(6), 838-849.

Jamali, D. (2010). The CSR of MNC Subsidiaries in Developing Countries: Global, Local, Substantive or Diluted, Journal of Business Ethics, 93: 181-200.

Jamali, D. and Kechichian, T. (2008). Uneasy alliances: lessons learned from partnerships between businesses and NGOs in the context of CSR, Journal of Business Ethics, 84, 277-295.

Jamali, D., Neville, B. (2011). Convergence Versus Divergence of CSR in Developing Countries: An Embedded Multi-Layered Institutional Lens, Journal of Business Ethics, 102(4), 599-621.

Kolk, A. (2016). The social responsibility of international business: From ethics and the environment to CSR and sustainable development, Journal of World Business, 51(1), 23-34.

Logsdon, J., Wood, D. (2002). Business Citizenship: From Domestic to Global Level of Analysis, Business Ethics Quarterly, 12(2), 155-187.

Matten, D., Moon, J. (2008). «Implicit» and «Explicit» CSR: A Conceptual Framework for a Comparative Understanding of Corporate Social Responsibility, The Academy of Management Review, 33(2), 404-424.

Meyer, J.W., Rowan, B. (1977). Institutionalized organizations: Formal structure as myth and ceremony. American Journal of Sociology, 83(2), 340-363

Miles, M.B., Huberman, A.M. (1994). Qualitative Data Analysis, Sage: Thousand Oaks.

Miska, C., Witt, M.A., Stahl, G. (2016). Drivers of Global CSR Integration and Local CSR Responsiveness: Evidence from Chinese MNEs, Business Ethics Quarterly, 26(3), 317-345.

Mohan, A. (2006). Global corporate social responsibilities management in MNCs, Journal of Business Strategies, 23(1), 3-25.

Park, B.I., Chidlow, A., Choi, J. (2014). Corporate social responsibility: Stakeholders influence on MNEs' activities, International Business Review, 23(5), 966-980.

Park, B.I., Ghauri, P.N. (2015). Determinants influencing CSR practices in small and medium sized MNE subsidiaries: A stakeholder perspective, Journal of World Business, 50(1), 192-204. 
R. Szanto. CSR Dilemmas at Multinational Companies: Global Pressures vs. Local Expectations in the Lights of the Hungarian Evidence

Pataki, Gy., Szanto, R., Matolay, R. (2015). CSR Online and in Real Terms: A Critical Analysis of Controversial Sectors in Hungary, In. Adi, A., Grigore, G., \& Crowther, D. (eds.). Corporate Social Responsibility in the Digital Age (pp. 241-264), Emerald Group Publishing Limited.

Pisani, N., Kourula, A., Kolk, A., Meijer, R. (2017). How global is international CSR research? Insights and recommendations from a systematic review, Journal of World Business, 52(5), 591-614.

Rathert, N. (2016). Strategies of legitimation: MNEs and the adoption of CSR in response to host-country institutions, Journal of International Business Studies, 47(7), 858-879.

Rodriguez, P., Siegel, D.S., Hillman, A., Eden, L. (2006). Three Lenses on the Multinational Enterprise: Politics, Corruption, and Corporate Social Responsibility, Journal of International Business Studies 37, 733-746.

Sroka, W., Szanto, R. (2018). Corporate Social Responsibility and Business Ethics in Controversial Sectors: Analysis of Research Results, Journal of Entrepreneurship, Management and Innovation, 14(3), 111-126.

Surroca, J., Tribo, J.A., Zahra, S.A. (2013). Stakeholder pressure on MNEs and the transfer of socially irresponsible practices to subsidiaries The Academy of Management Journal, 56(2), 549-572.

Szanto, R. (2018). The Online Communication of Corporate Social Responsibility in Subsidiaries of Multinational Companies in Hungary, Organizacija, 51(3), 160-168.

Tan, J., Wang, L. (2011). MNC Strategic Responses to Ethical Pressure: An Institutional Logic Perspective, Journal of Business Ethics, 98(3), 373-390.

Wisniewski, M. (2015). CSR risk management, Forum Scientiae Oeconomia, 3(4), 17-24

Yin, J., Jamali, D. (2016). Strategic Corporate Social Responsibility of Multinational Companies Subsidiaries in Emerging Markets: Evidence from China, Long Range Planning, 49(5), 541-558.

Річард Шанто, Ph.D., Університет Корвінуса в Будапешті (Угорщина).

КСВ-дилеми мультинаціональних компаній на прикладі Угорщини: глобальний тиск та локальні очікування

Низка проведених досліджень свідчить про те, що реалізація ініціатив корпоративної соціальної відповідальності (КСВ) та діяльність мультинаціональних компаній (МНК) відрізняються залежно від регіону. При цьому дочірні підприємства МНК повинні реагувати як на виклики міжнародного ринку, так і враховувати інтереси місцевих стейкхолдерів. У статті досліджено КСВ-дилеми мультинаціональних компаній. Дослідження здійснено в наступній логічній послідовності: визначено основні стимули проведення заходів у рамках політики КСВ та встановлено оптимальне співвідношення між глобальним тиском МНК та очікуваннями зацікавлених сторін на локальному рівні; виявлено механізми, які використовуються з метою урегулювання проблем; проведено 10 півструктурованих дослідницьких інтерв'ю на рівні Угорських дочірніх компаній; виявлено 3 ключові проблеми, а також 7 механізмів їх вирішення. Автором зазначено, що до трьох ключових проблем належать: недостатність фрінансових та трудових ресурсів у сфері КСВ, відсутність правової та культурної підтримки ініціатив головного офрісу, а також виникнення складнощів у процесі формування ефективної стратегії у відповідь на багаточисленні потреби стейкхолдерів. У свою чергу, автором наголошено, що дочірні підприємства використовують різні механізми у процесі вирішення проблем. Загалом, дочірні підприємства націлені на ведення переговорів із головним офрісом МНК з метою отримання достатнього рівня фінансових ресурсів для проведення КСВ заходів на локальному рівні, а також отримання свободи у фінансування заходів імплементації КСВ. У випадку неможливості накопичення великого запасу ресурсів, доцільним є прийняття стриманої або мінімальної стратеаії КСВ, яка, по суті, являється філантропією чи благодійністю. У свою чергу, у тому випадку, коли соціальні цінності країни, де фрункціонує, МНК не відповідають ї глобальним цілям, дочірні компанії часто надають перевагу стратеаії «замикання в собі», тобто просування глобальних цінностей в щоденні операції в межах однієї компанії без поширення їх у практику інших. При цьому дочірні компанії використовують відповідні механізми з метою виявлення потреб основних стейкхолдерів та формування таких заходів, які $є$ невід'ємними елементами їх локальних КСВ стратеаій. Автором зазначено, що дочірні компанії часто співпрацюють із нерядовими громадськими організаціями та/або органами місцевого самоврядування задля досягнення власних КСВ-цілей. У статті визначено, що більщість дочірніх компаній аналізують діяльність інших підрозділів МНК у регіоні з метою виявлення дієвих механізмів протистояння їх локальним КСВ-проблемам.

Ключові слова: механізм пристосування, корпоративна соціальна відповідальність, локальна КСВ, глобальна КСВ, мультинаціональні компанії, дочірні компанії.

Manuscript received: 20.03.2019.

(C) The author(s) 2019. This article is published with open access at Sumy State University. 